\title{
WATER RELATIONS AND PHOTOSYNTHESIS AS CRITERIA FOR ADEQUATE IRRIGATION MANAGEMENT IN 'TAHITI' LIME TREES
}

\author{
Cláudio Ricardo da Silva ${ }^{1}$; Marcos Vinícius Folegatti ${ }^{3 *}$; Tonny José Araújo da Silva ${ }^{1,2}$; José \\ Alves Júnior ${ }^{1}$; Claudinei Fonseca Souza ${ }^{4}$; Rafael Vasconcelos Ribeiro ${ }^{2}$ \\ ${ }^{I}$ USP/ESALQ - Programa de Pós-Graduação em Irrigação e Drenagem, C.P. 9 - 13418-900 - Piracicaba, SP - \\ Brasil. \\ APTA/IAC - Centro de Pesquisa e Desenvolvimento de Ecofisiologia e Biofísica, C.P. 28 - 13001-970 - Campinas, \\ $S P$ - Brasil. \\ ${ }^{3}$ USP/ESALQ - Depto. de Engenharia Rural, C.P. 9 - 13418-900 - Piracicaba, SP - Brasil. \\ ${ }^{4}$ UNITAU - Depto. de Engenharia Civil e Ambiental, 12020-330, Taubaté, SP. \\ *Corresponding author <mvfolega@esalq.usp.br>
}

ABSTRACT: Irrigation scheduling based on soil moisture status is one of the most useful methods because of its practicality and low cost. The effects of available soil water depletion on evapotranspiration (ETc), transpiration $(E)$, leaf water potential at predawn $\left(\Psi_{P}\right)$ and midday $\left(\Psi_{M}\right)$, stomatal conductance $(g s)$ and net $\mathrm{CO}_{2}$ assimilation $(A)$ in lime 'Tahiti' trees (Citrus latifolia) were evaluated to improve irrigation schedule and minimize water use without causing water stress. The trees were spaced $7 \times 4 \mathrm{~m}$ and drip-irrigated by four drippers with the available soil water content $(A W C)$ depleted by suspension of irrigation (40 days). Leaf water potential was measured on a pressure chamber $\left(\Psi_{P}\right.$ and $\left.\Psi_{M}\right)$ and leaf gas exchange was measured by infrared gas analyzer ( $E$, gs and $A$ ). Evapotranspiration was determined with the aid of weighing lysimeter. Water soil content and potential $\left(\Psi_{S}\right)$ were monitored with TDR probes and tensiometers, respectively, installed at $0.3,0.6$ and $0.9 \mathrm{~m}$ depths. Meteorological variables were monitored with an automatic weather station in the experimental area. The threshold AWC level for the onset of ETc decline was $43 \%$, and $60 \%$ for $g s, A, E$ and $\Psi_{P}$. Also, $\Psi_{P}$ was more sensitive to $A W C$ than $\Psi_{M}$, and is therefore a better tool for irrigation. When $A W C$ was around $60 \%$, values of $\Psi_{P}$ and $\Psi_{S}$ were $-0.62 \mathrm{MPa}$ and $-48.8 \mathrm{kPa}$, respectively.

Key words: evapotranspiration, citrus, lysimeter, gas exchange, tensiometer

\section{RELAÇÕES HÍDRICAS E FOTOSSÍNTESE COMO CRITÉRIOS PARA MANEJO ADEQUADO DA IRRIGAÇÃO EM PLANTAS DE LIMEIRA 'TAHITI'}

\begin{abstract}
RESUMO: Programar práticas de irrigação com base na umidade do solo é um dos métodos mais usuais devido sua praticidade e baixo custo. O efeito do esgotamento da água disponível do solo sobre a evapotranspiração $(E T c)$, transpiração $(E)$, potencial de água na folha ao amanhecer $\left(\Psi_{P}\right)$ e ao meio-dia $\left(\Psi_{M}\right)$, condutância estomática ( $g s)$ e assimilação líquida de $\mathrm{CO}_{2}(A)$ em plantas de limeira 'Tahiti' (Citrus latifolia) foi avaliado para melhorar o manejo da irrigação, minimizando água e evitando o estresse hídrico. As plantas foram espaçadas de $7 \times 4 \mathrm{~m}$ e irrigadas por quatro gotejadores com a diminuição da água disponível no solo $(A D)$ provocada pela suspensão da irrigação (40 dias). Para as medidas do potencial da água na folha foi utilizado uma câmara de pressão $\left(\Psi_{P}\right.$ e $\left.\Psi_{M}\right)$ e para as medidas de trocas gasosas um analisador de gases por infravermelho $(A, E$ e gs). Foi utilizado um lisímetro de pesagem para a determinação da $E T c$. A umidade e potencial de água no solo $\left(\Psi_{S}\right)$ foram monitoradas por sondas de TDR e tensiômetros, respectivamente, instalados a $0,3,0,6$ e $0,9 \mathrm{~m}$ de profundidade. As variáveis meteorológicas foram monitorados por uma estação agrometeorológica automática na área. O limite de $A D$ na qual a $E T c$ começou a diminuir foi de $43 \%$, ao passo que para $g s, A, E$ e $\Psi_{P}$ foi de $60 \%$. Ainda, o $\Psi_{P}$ foi mais sensível a $A D$ do que as medidas de $\Psi_{M}$ podendo ser recomendado como ferramenta para manejo de irrigação. Quando $A D$ estava próximo de $60 \%$, os valores de $\Psi_{P}$ e $\Psi_{S}$ eram -0,62 MPa e - $48,8 \mathrm{kPa}$, respectivamente.

Palavras-chave: evapotrasnpiração, citros, lisímetro, trocas gasosas, tensiômetro
\end{abstract}

\section{INTRODUCTION}

Increasing world water scarcity and irrigation costs demand developing irrigation methods that mini- mize water use (Jones, 2004). Localized systems such as microsprinkler and drip irrigation play a major role in reducing the amount of water applied to agricultural crops (Folegatti et al., 2004). However, the maximum 
water use efficiency depends on adequate irrigation scheduling.

Irrigation scheduling based on soil moisture status is one of the most useful methods because of its practicality and low cost. The principle is that soil moisture can be decreased to a threshold in which water can no longer be transported quickly enough to the roots to respond to transpirational demand, triggering crop water stress (Allen et al., 1998).

A well-known mechanism to prevent plant dehydration under environmental constraint is the stomatal closure (Hall et al., 1975; Syvertsen, 1982; Savé et al., 1995). This response affects both transpiration and photosynthesis of citrus species in different degrees, depending on water stress level (Vu \& Yelenosky, 1988; Medina et al., 1998; 1999).

The threshold level of available soil water ( $S W A)$ that can be depleted is usually determinated by comparing the long-term relationship between yield or tree development and soil moisture levels for a particular location. Moisture levels can be more accurately assessed using plant physiological characteristics such as stomatal conductance, net $\mathrm{CO}_{2}$ assimilation, leaf water potential and fruit or trunk growth (Davies \& Albrigo, 1994). However, few experimental studies use these approaches under field conditions and focus on irrigation scheduling. The purpose of this work was establishing an adequate threshold for available soil water using physiological characteristics to minimize water use in 'Tahiti' lime trees.

\section{MATERIAL AND METHODS}

\section{Experimental area}

The experiment was carried for 40 days at the end of the winter season, 2004, in a 1.0-ha plot planted in 2001 with 'Tahiti' acid lime trees (Citrus latifolia Tanaka), grafted on 'Swingle' [Poncirus trifoliata (L.) Raf. $\times$ Citrus paradisi Macf.] citrumelo rootstock. Trees were spaced $7 \times 4 \mathrm{~m}$ and drip-irrigated by four, pressurecompensated drippers each, flow rate $4 \mathrm{~L} \mathrm{~h}^{-1}$, emission uniformity $95 \%$. The irrigation was automatically controlled by a head unit programmer and electro-hydraulic valves. The fraction of wetted area in relation to tree canopy cover at a $0.3 \mathrm{~m}$ depth under $3 \mathrm{~h}$ of irrigation was around $22 \%$.
The orchard was located in Piracicaba, São Paulo

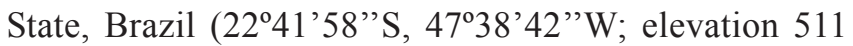
$\mathrm{m})$. Average annual temperature in the area is $21.4^{\circ} \mathrm{C}$ and annual rainfall is $1257 \mathrm{~mm}$. Along the study period, the rainfall was $8.5 \mathrm{~mm}$, and average air temperature, relative humidity and reference evapotranspiration were $22.2^{\circ} \mathrm{C}, 61 \%$ and $3.9 \mathrm{~mm}$, respectively. The soil is a Rhodic Kandiudalf, clay texture, $5 \%$ average slope. Available water capacity was $125 \mathrm{~mm} \mathrm{~m}^{-1}$, and the bulk density was $1300 \mathrm{~kg} \mathrm{~m}^{-3}$ determined over soil samples collected every $0.2 \mathrm{~m}$ down to $1.0 \mathrm{~m}$ deep.

Orchard floor was kept cleaned during the experimental period. Ordinary pest control practices were performed and the fertilization was done as recommend by Raij et al. (1992).

\section{Lysimetric and plant measurements}

A weighing lysimeter $(4 \mathrm{~m} \times 1.3 \mathrm{~m}$ depth $)$ (Campeche, 2002) containing one tree, was located near the center of the experimental area. The lysimeter was repacked with soil during installation to equalize bulk densities to the surrounding field. Weight variations were transmitted through three electronic cells to a data logger recording and storing the load cell output every at night time $(24 \mathrm{~h} 00)$ when calm conditions prevailed (average wind $<1.5 \mathrm{~m} \mathrm{~s}^{-1}$ ). Combined calibration and voltage reading errors elicited $0.82 \mathrm{~kg}$ accuracy. Daily crop evapotranspiration $(E T c)$ was calculated from changes in lysimeter weight and converted to $\mathrm{mm} \mathrm{d}^{-1}$, based on lysimeter surface area $\left(12.56 \mathrm{~m}^{2}\right)$. The lysimeter was irrigated and managed like all plants in the area.

In the experimental plot, six trees with similar structure and development were chosen and divided into two groups (treatments): irrigated $(X)$, where daily irrigation based on evapotranspiration was applied during the whole experiment; and non-irrigated $(Y)$ where irrigation was suspended. Plant growth measurements - tree height, trunk circumference, and canopy diameter - were taken on each treatment (Table 1). Canopy volume was calculated using the procedure of Hutchinson (1977).

\section{Estimation of available water and soil water potential} Measurements of soil volumetric water content in $X$ and $Y$ trees were made with a TDR cable tester (model 1502 C Tektronix, Beaverton, OR, USA) every three days.

Table 1 - Characteristics of lysimeter-grown tree, irrigated and non-irrigated 'Tahiti' lime trees before starting the experimental period.

\begin{tabular}{|c|c|c|c|c|}
\hline Plant & Height & Canopy diameter & Canopy volume & Trunk circumference \\
\hline & \multicolumn{2}{|c|}{ - } & $\mathrm{m}^{3}$ & $\mathrm{~m}$ \\
\hline Irrigated $(X)^{1}$ & $3.25 \pm 0.23$ & $3.59 \pm 0.06$ & $10.47 \pm 0.62$ & $0.35 \pm 0.02$ \\
\hline Non-irrigated $(\mathrm{Y})^{1}$ & $3.32 \pm 0.13$ & $3.63 \pm 0.08$ & $10.90 \pm 0.71$ & $0.34 \pm 0.03$ \\
\hline Lysimeter & 3.05 & 3.60 & 9.88 & 0.32 \\
\hline
\end{tabular}

${ }^{1}$ Mean \pm SE $(n=3)$. 
Three-wire TDR probes were installed $0.3,0.6$ and 0.9 $\mathrm{m}$ deep in the soil, and at $1.0 \mathrm{~m}$ laterally from trunk of trees, under wetted dripper area. The dielectric constant $(K a)$ of the soil was converted to soil volumetric water content by a calibration obtained for this soil (Tommaselli \& Bacchi, 2001). Soil water potential ( $\Psi_{S}$ ) was monitored with tensiometers set $0.6 \mathrm{~m}$ deep $(\mathrm{n}=$ $3)$. Daily variations in available soil water in lysimetergrown were monitored by water potential sensors (Watermark $^{\circledR}$ model 253-L; Campbell Scientific, Logan, UT, USA) connected to the lysimeter data logger, at the same depth of TDR sensors. The soil water potentials were converted to soil volumetric water content by the Soil Water Retention Curve fitting software (Van Genuchten, 1980).

The available soil water content $(S W A)$ was calculated with the aid of the equation:

$$
S W A=\left[\frac{(\theta a-\theta p w p)}{(\theta f c-\theta p w p)}\right] \times 100
$$

where: $S W A=$ available soil water content, $\%, \theta_{f c}=$ soil volumetric water content at field capacity, $\mathrm{m}^{3} \mathrm{~m}^{-3}(10$ $\mathrm{kPa}), \theta_{p w p}=$ soil volumetric water content at the permanent wilting point, $\mathrm{m}^{3} \mathrm{~m}^{-3}(1500 \mathrm{kPa}), \theta_{a}=$ average soil volumetric water content (between $0.3,0.6$ and $0.9 \mathrm{~m}$ depth), $\mathrm{m}^{3} \mathrm{~m}^{-3}$

\section{Leaf water potential measurements}

Leaf water potential was measured every three days at predawn $\left(\Psi_{P} ; 06 \mathrm{~h} 00-06 \mathrm{~h} 30\right)$ and at noon $\left(\Psi_{M}\right.$; 12h00-12h30) with a Scholander-type pressure chamber (model 3005; Soil Moisture Equipment Corporation, Santa Barbara, CA, USA). At each measurement time, two stems (four to eight leaves) per tree were sampled by excision in the northward portion of the canopy, at about $1.5 \mathrm{~m}$ of the soil surface.

\section{Leaf gas exchange measurements}

Two, fully-expanded, similar leaves at external canopy positions per tree per treatment, were sampled for gas exchange measurements. Net $\mathrm{CO}_{2}$ assimilation $(A)$, transpiration $(E)$, and stomatal conductance $(g s)$ were determined every three days at $09 \mathrm{~h} 30-10 \mathrm{~h} 30$ with a portable photosynthesis system (IRGA, model LI-6400, Li-Cor, Lincoln, NE, USA) on the same days that soil and leaf water potentials were determined. Incident photosynthetic photon flux density (PPFD) was fixed based on environmental conditions just prior to the beginning of measurements (Figure 2A), using an artificial quartz halide light source (LI-6400-02 LED light source, Li-Cor) controlled with a quantum sensor inside the leaf cuvette. Air $\mathrm{CO}_{2}$ concentration was fixed at $350 \pm 10 \mu \mathrm{mol} \mathrm{mol}^{-1}$. The actual Water Use Efficiency ( $W U E$ ) was calculated as $A / E$ (Machado et al., 1999).

\section{Determining the available soil water and its threshold} level

The relationship between $(E T c)$ and the reference evapotranspiration $(E T o)$ was determined before the beginning of the experiment. Both ETo and meteorological variables were obtained from an automatic weather station (model CR21x; Campbell Scientific, Logan, UT, USA) equipped with sensors for air temperature, relative humidity, global and net radiation, wind speed and Penman-Monteith algorithm (Allen et al., 1998), located 70 $\mathrm{m}$ away from lysimeter. Irrigation water was applied daily from day one to 15 of the trial lysimeter, to compensate $E T c$ losses of the previous day. An average crop coefficient $(E T c / E T o)$ was obtained and ETc was thus estimated as $0.89 \times E T o$ during the deficit irrigation period. Plants of treatment $X$ were irrigated based on ETo and a crop coefficient of 1.0 (one) to ensure that no water limitation would occur.

Irrigation in non-irrigated $(Y)$ and lysimetergrown trees was suspended on the $16^{\text {th }}$ day of the trial. Lysimeter's evapotranspiration was then considered (recorded) measured evapotranspiration $\left(E T_{R}\right)$ and compared to the estimated ETc $(0.89 \times E T o)$. When the relationship $E T_{R} / E T C$ was lower than 1.0 (one), the threshold level of available soil water $(S W A)$ based on evapotranspiration was determined. This procedure was also adopted to establish the threshold level of $S W A$ based on $A, E, g_{S}, \Psi_{P}$, and $\Psi_{M}$

\section{RESULTS AND DISCUSSION}

\section{Evapotranspiration}

Estimated tree evapotranspiration $(E T c)$ and measured evapotranspiration $\left(E T_{R}\right)$ during the drying period (Figure 1A) tended to increase from day one of the experimental period, with the exception of two pronounced troughs (at days 13 and 33) caused by decreases in both global and net radiation, as well as air vapor pressure deficit (Figures 2A and B). The time-course of the relative evapotranspiration $\left(E T_{R} / E T c\right)$ was almost constant along the first 25 days after the beginning of the drying period, varying around one when the available soil water content $(S W A)$ was higher than $43 \%$, and then declining sharply (Figure 1B). This result was close to a $S W A$ of $46 \%$ reported by Allen et al. (1998) under similar environmental conditions and citrus tree development. However, it was lower than that threshold level recommended by Marler \& Davies (1990) to 'Hamilin' trees (from 65 to $70 \%$ ) in Florida. When SWA was around $43 \%$, values of leaf and soil water potential were $\Psi_{P}=-0.79 \mathrm{MPa}$, $\Psi s=-82.1 \mathrm{kPa}(0.6 \mathrm{~m})$. That suggests some level of water stress when compared with the results of $\mathrm{Vu} \&$ Yelenosky (1988) and Machado et al. (2002). Pires (1992) suggested irrigating citrus when $\Psi_{S}$ is between -50 and $70 \mathrm{kPa}$. Medina \& Machado (1998) did not observe 


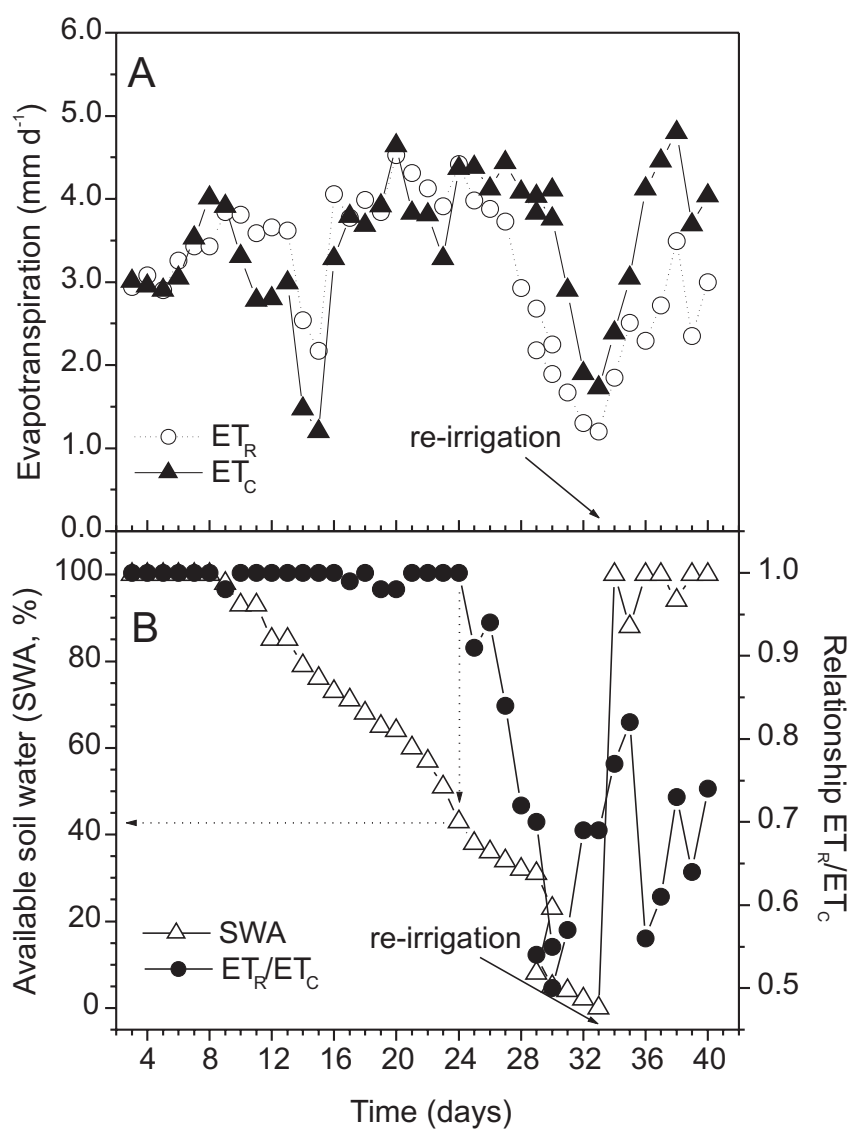

Figure 1 - Estimated crop evapotranspiration $(E T c)$ and measured evapotranspiration $\left(E T_{R}\right)$ throughout the experiment (A). Relative evapotranspiration $\left(E T_{R} / E T C\right)$ and available soil water $(S W A)(\mathrm{B})$. The arrow indicates when the lysimetergrown tree was re-irrigated, 34 days after the beginning of the experimental period.

changes in $A, E, W U E$, leaf water potential and leaf relative water content in 'Valencia' oranges when the substrate water potential was higher than $-40 \mathrm{kPa}$. Shalhevet \& Levy (1990) suggested that $\Psi_{P}$ should be maintained higher than $-0.72 \mathrm{MPa}$ to avoid water stress, but there may be large variability between plant species.

Thirty-four days after suspension of irrigation, the lysimeter-grown tree showed general leaf chlorosis with severe stress $\left(\Psi_{P}=-2.70 \mathrm{MPa}\right)$, and thus irrigation was reestablished. Even after re-irrigation, $E T_{R} / E T c$ remained lower than 1.0 (one) until the end of the experiment period. Ginestar \& Castel (1996) reported that two weeks of irrigation were necessary for total rehydration of 'Clementine' mandarin trees subjected to severe water stress $\left(\Psi_{P}=-4.0 \mathrm{MPa}\right)$ under field conditions. The involvement of stomata is among the factors causing nonrecovery of $E T_{R}$. There was only partial recovery of stomatal opening in stressed 'Valencia' orange trees after reirrigation (Medina et al., 1999). This recovery delay may be associated to accumulation of abscisic acid in the leaves during drying cycle (Davies \& Zhang, 1991; Liu et al., 2003) or to damages to biochemical and/or photo-

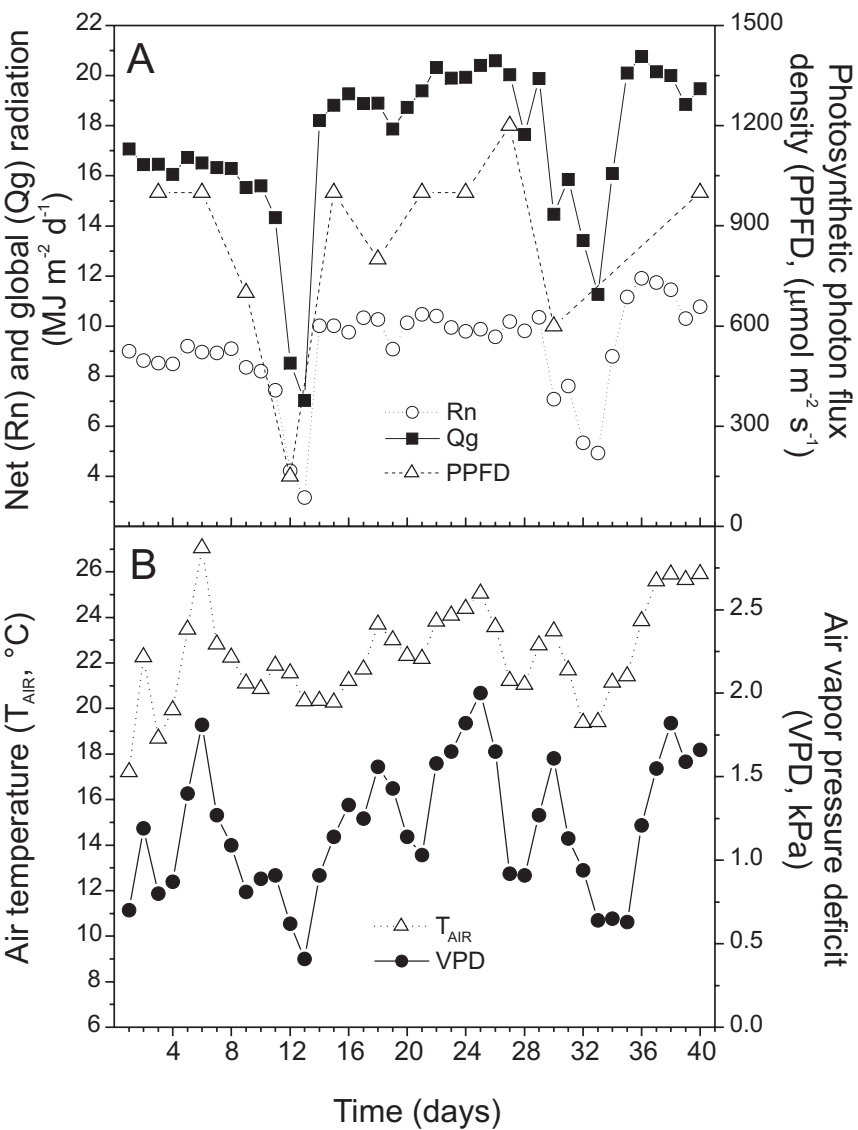

Figure 2 - Net and global radiation, photosynthetic photon flux density (A), air temperature and air vapor pressure deficit (B) throughout the experiment.

chemical processes of photosynthesis, which reduce stomatal conductance via increased intercellular $\mathrm{CO}_{2}$ concentration (Wong et al., 1979).

\section{Leaf gas exchange}

Mean values of $A, g s$ and $E$ in irrigated plants ranged from 4 to $7 \mu \mathrm{mol} \mathrm{m} \mathrm{m}^{-2} \mathrm{~s}^{-1}, 0.05$ to $0.11 \mathrm{~mol} \mathrm{~m}^{-2} \mathrm{~s}^{-1}$, and 1.2 to $2.60 \mathrm{mmol} \mathrm{m}^{-2} \mathrm{~s}^{-1}$, respectively (Figure 3). These values are lower than those reported under optimum environmental conditions (Syvertsen \& Lloyd, 1994), especially for $A$ which normally varies between 12 and $14.5 \mu \mathrm{mol} \mathrm{m}^{-2} \mathrm{~s}^{-1}$ (Medina, 2003). Such a difference was probably caused by fluctuations of environmental elements, such as $P P F D$, air temperature, and relative humidity to levels below those for optimum physiological, along the experimental period. Seasonal effects on leaf gas exchange had already been reported by Machado et al. (2002) who recorded higher photosynthetic rates on citrus trees during summer than in winter.

There were significant differences in $g S, A$ and $E$ between irrigated and non-irrigated trees only when $S W A$ was below $60 \%$ (Figures 3B, D and F). In such condi- 

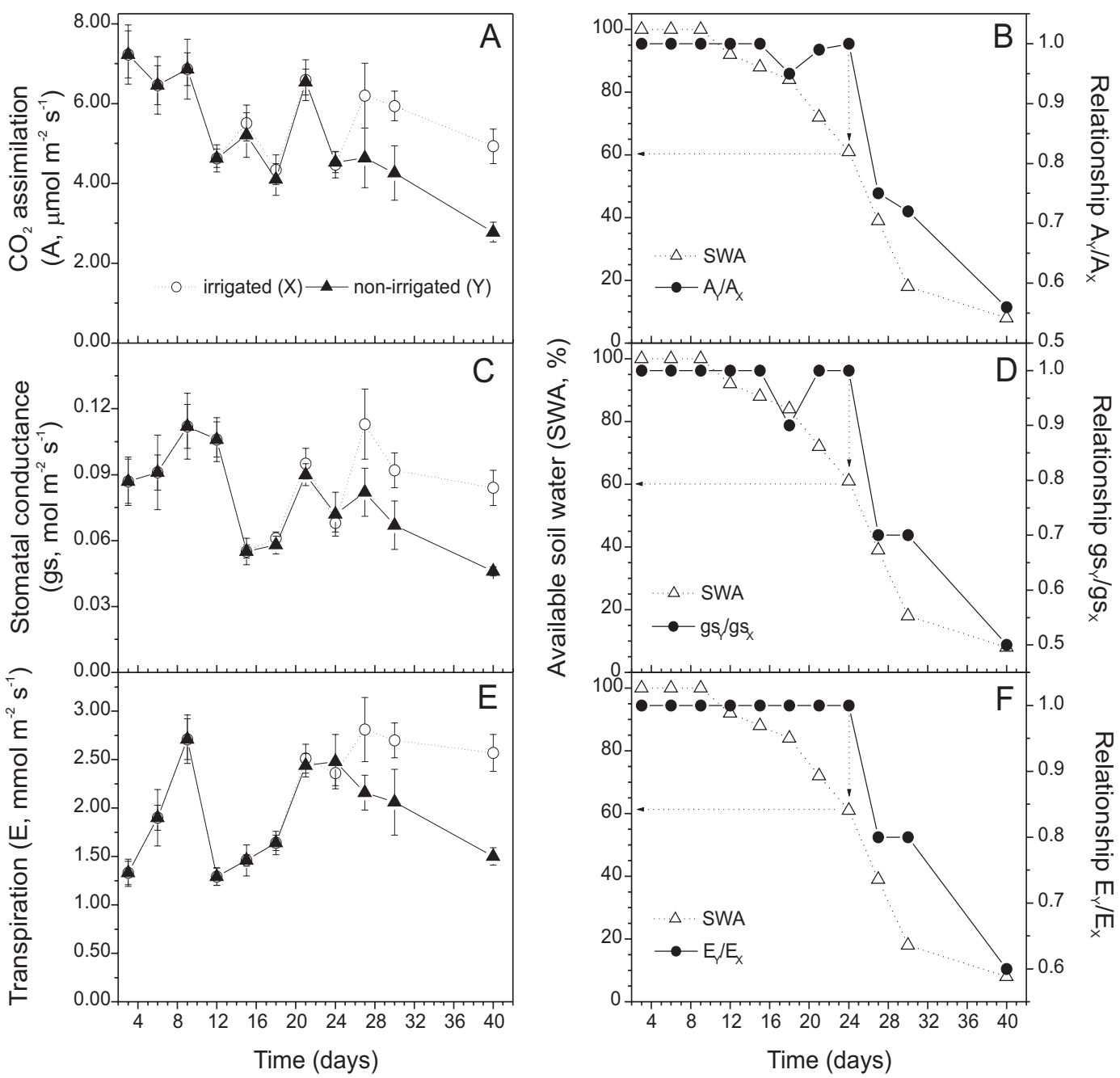

Figure 3 - Time-course of $\mathrm{CO}_{2}$ assimilation (A) stomatal conductance (C), and transpiration (E) in irrigated $(X)$ and non-irrigated 'Tahiti' lime trees $(Y)$. Relationships between physiological variables and soil water content $(S W A)$ throughout the experiment: $\mathrm{CO}_{2}$ assimilation (B); stomatal conductance (D); transpiration (F). Each point represents the mean value $\pm \mathrm{SE}(\mathrm{n}=6)$.

tions, the mean values of leaf and soil water potential were -0.62 and $-48.8 \mathrm{kPa}(0.6 \mathrm{~m})$, respectively.

The leaf gas exchange measurements were more sensitive to $S W A$ than evapotranspiration measured in the lysimeter. The reduction on stomatal conductance did not decrease the evapotranspiration possibly because leaf gas exchange measurements were taken in leaves located externally to the canopy and completely exposed to solar radiation, an unfavorable environmental condition in comparison to conditions inside tree canopy. Shaded leaves have higher leaf water potential and, as a consequence, higher stomatal aperture and transpiration (Syvertsen et al., 1981). Therefore, non-exposed leaves could have contributed to the maintenance of optimum evapotranspiration rates up to $43 \% S W A$.

Water use efficiency ( $W U E$ ) during the water withholding period as well as the relationship $W U E_{Y} /$ $W U E_{X}$ and $S W A$ are shown in Figure 4. Since there were no differences between irrigated and non-irrigated trees (Figure 4A), it can be speculated that 'Tahiti' lime trees use the stomatal control mechanism to prevent plant dehydration and preserve plant water status. Brakke \& Allen $\mathrm{Jr}$ (1995) did not find significant changes in WUE of citrus when comparing measurements taken at $S W A$ ranging on 37 to $56 \%$. The determination of a threshold level of $S W A$ based on the relationship $W U E_{Y} / W U E_{X}$ was not possible since it did not vary $\left(W U E_{Y} / W U E_{X} \approx 1.0\right)$ along the experimental period (Figure 4B).

\section{Leaf water potential}

After 24 days of water deficit, $\Psi_{P}$ and $\Psi_{M}$ were reduced with $\Psi_{P}$ showing significant decrease and reaching -0.9 MPa (Figure 5A). Although non-irrigated plants had shown different $\Psi_{P}$ and $\Psi_{M}$ in comparison to irrigated plants, the latter exhibited low mean throughout the experimental period (-0.57 MPa). The $\Psi_{P}$ values were lower than the values recorded for the same irrigated trees during rainy summer $(-0.35 \mathrm{MPa})$ even for the well-irrigated plants. Small wetted soil area (22\% in this study) may lead to partial root wetting and reduction of $\Psi_{P}$ as con- 

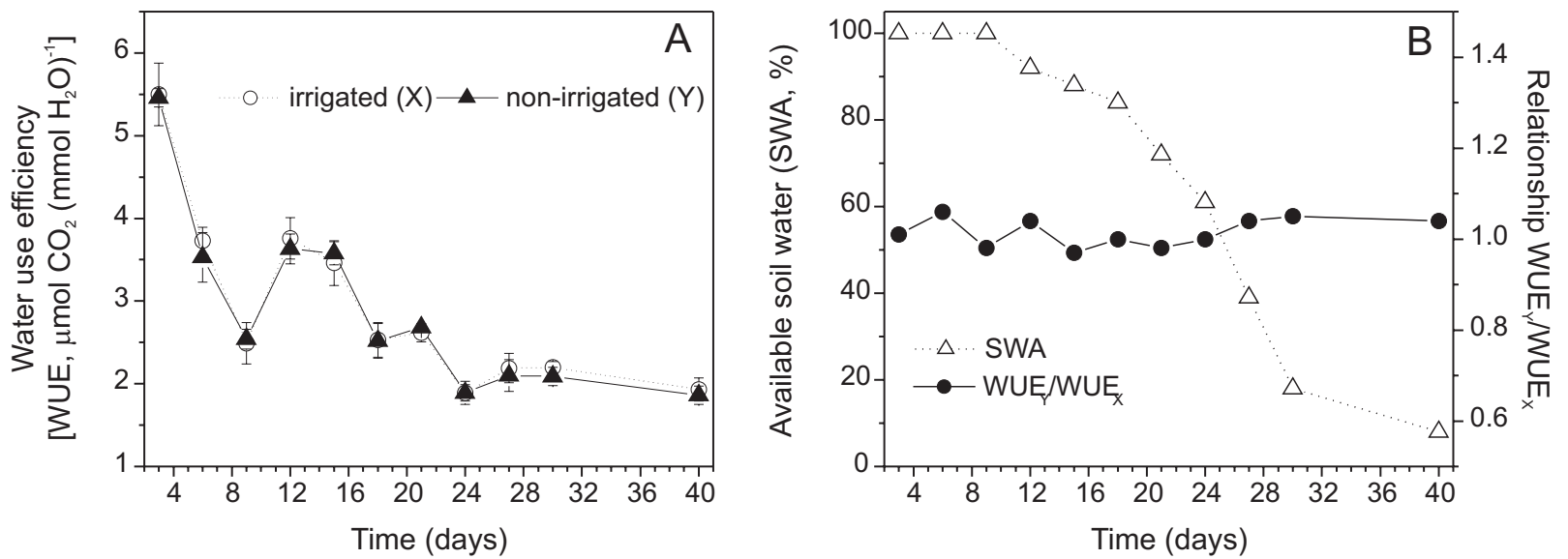

Figure 4 - Water use efficiency (WUE) (A), relationship between $W U E$ in irrigated $(X)$ and non-irrigated $(Y)$ 'Tahiti' lime trees and soil water content $(S W A)$ throughout the experiment $(B)$. Each point represents the mean value $\pm \operatorname{SE}(n=6)$.
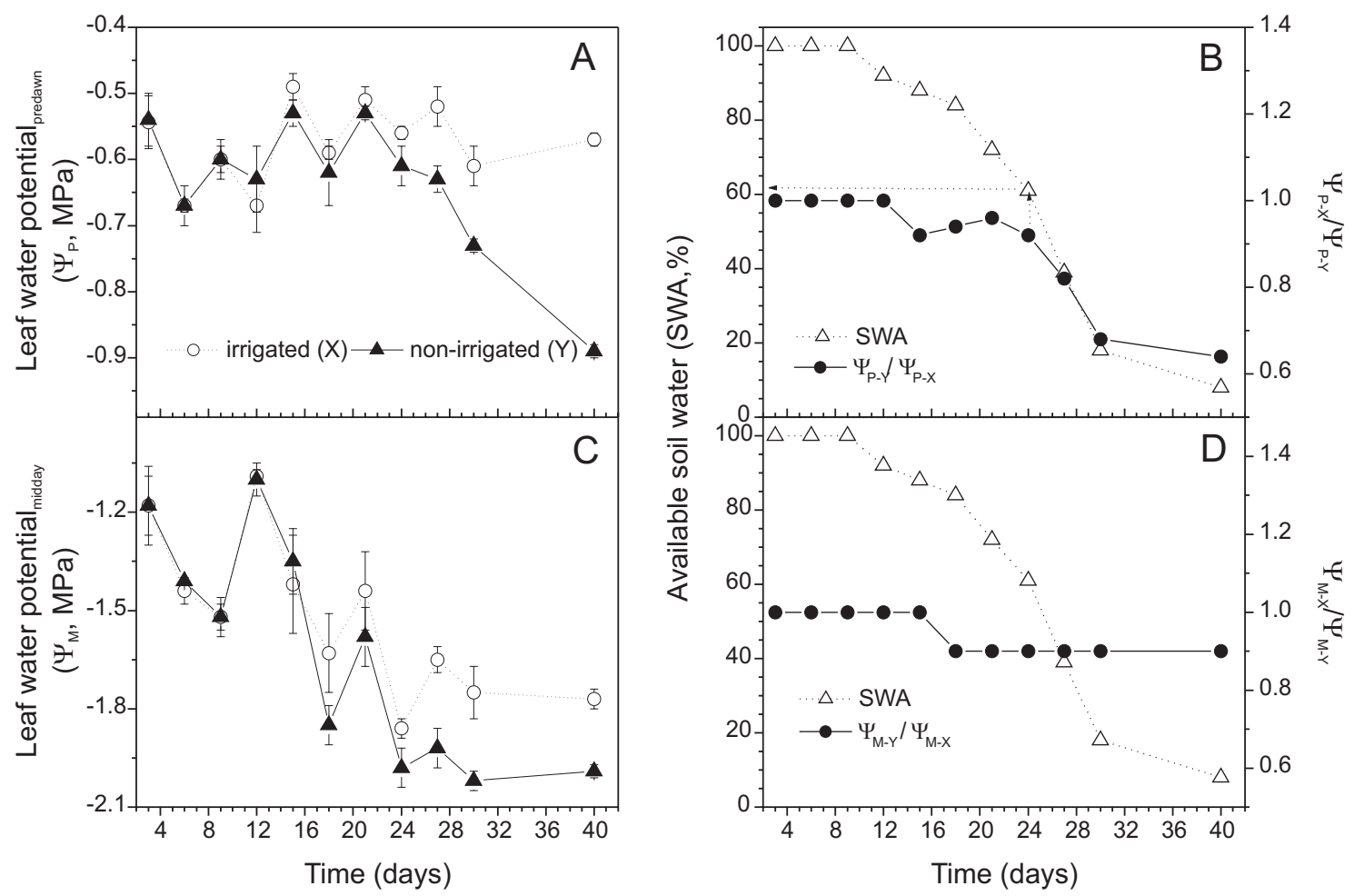

Figure 5 - Leaf water potential of 'Tahiti' lime measured at predawn (A) and noon (C) in irrigated $(X)$ and non-irrigated plots $(Y)$ throughout the experiment. The relationship between relative leaf water potential $(X / Y)$ measured at predawn (B) and noon (D) and soil water content $(S W A)$. Each point represents the mean value $\pm \operatorname{SE}(n=6)$.

sequence. Bernardo (1995) and Vermeiren \& Jobling (1997) recommend the wetting of $50 \%$ of the potential zone root in perennial crops. Results of some recent, long-term experiments evaluating yield and citrus tree development under different levels of wetted area, have agreed that the wetting of around $50 \%$ of tree soil surface area is the ideal procedure (Bielorai, 1982; Smajstrla \& Koo, 1984; Castel, 1994; Souza et al., 2003). However, Gowing et al. (1990) reported reduction of transpiration and leaf expansion in apple trees that had $50 \%$ of wetted roots when compared to well- irrigated ones. This is an important consideration to be made since increasing wetted area results in high irrigation costs by increasing the number of emitters, tube diameter, and water pump power. The soil temperature dropped to $7.5^{\circ} \mathrm{C}$ during the experimental period, so it can be hypothesized that the low soil temperature could have affected the root hydraulic conductivity and root hormone content and, consequently, the hydration of shoot tissues (Elfving et al., 1972; Veselova et al., 2003). However, Machado et al. (2002) did not found environmental influence on leaf water potential at predawn on 
potted citrus plants during either January, March or July, despite differences in leaf gas exchange being recorded. During the experimental period, large variations in $\Psi_{M}$ were observed on both treatments, and probably reflect weather conditions, as observed in other studies (Scholander et al., 1965; Southwick \& Davenport, 1987; Domingo et al., 1996; Jones, 2004).

The relative leaf water potential at predawn $\left(\Psi_{P-X} / \Psi_{P-Y}\right)$ decreased sharply when $S W A$ was lower than $60 \%$ (Figure 5B). However, the relative leaf water potential at noon $\left(\Psi_{M-X} / \Psi_{M-Y}\right)$ did not present steady drop as predawn measurements (Figure 5D), with a little drop to 0.9 when $S W A$ was close to $80 \%$, but remaining constant throughout the drying period. Some studies suggest that predawn values (maximum) are better indicators of irrigation needs than noon values (Shalhevet \& Levy, 1990; Ginestar \& Castel, 1996; Urribarrí et al., 1996; Domingo et al., 1996; González-Altozano \& Castel, 2000). In fact, plant tissues are hydrated to a maximum right before sunrise when there is no water restriction, whereas measurements taken at noon reflect transpiring tissues, use more nitrogen gas and are more susceptible to fluctuations of environmental conditions, especially incident radiation, air temperature, and vapor deficit pressure.

Although the SWA was almost depleted by the end of drying period, the lowest value of leaf water potential was around $-0.89 \mathrm{MPa}$, and higher than that obtained for the lysimeter-grown tree $\left(\Psi_{P}=-2.70 \mathrm{MPa}\right)$. This difference was probably caused by the fact that the root systems of field-grown trees were larger than that of the lysimeter-grown three, allowing better water uptake by the increased, exploited soil volume. Allied to the maintenance of $W U E$ (there were no differences between irrigated and non-irrigated plants, Figure 4A) this phenomenon indicates the great ability of field-grown trees in avoiding the negative effects of water deficit.

For irrigation scheduling purpose, SWA of $60 \%$ is the threshold level to avoid negative physiological effects. Such $S W A$ threshold level is correlated with leaf and soil water potentials of $-0.62 \mathrm{MPa}$ and $-48.8 \mathrm{kPa}$ (at 0.6 $\mathrm{m}$ depth), respectively.

\section{ACKNOWLEDGEMENTS}

The authors wish to thank the support received from Professors Dr. Carlos Guilherme Silveira Pedreira (ESALQ-USP), Dr. Rubens Duarte Coelho (ESALQ-USP) and Dr. Edson Eiji Matsura (FEAGRI-UNICAMP).

\section{REFERENCES}

ALlEN, R.; PEREIRA, L.S.; RAES, D.; SMITH, M. Crop evapotranspiration: guidelines for computing crop water requirements. Rome: FAO, 1998. 300p. (Irrigation and Drainage Paper, 56).

BERNARDO, S. Manual de irrigação. Viçosa: Imprensa Universitária, 1995. $657 \mathrm{p}$
BIELORAI, H. The effect of partial wetting of the root zone on yield and water use efficiently in a drip and sprinkler-irrigated mature grapefruit grove. Irrigation Science, v.3, p.89-100, 1982.

BRAKKE, M.; ALLEN Jr., L.H. Gas exchange of Citrus seedlings at different temperatures, vapor-pressure deficits, and soil water contents. Journal of the American Society for Horticultural Science, v.120, p.497-504, 1995.

CAMPECHE, L.F.S.M. Construção, calibração e análise de funcionamento de lisímetros de pesagem para determinação da evapotranspiração da cultura da lima ácida 'Tahiti' (Citrus latifolia Tan.). Piracicaba: USP/ ESALQ, 2002. 62p. (Tese - Doutorado).

CASTEL, J.R. Response of young citrus trees to drip irrigation. I. Irrigation amount and number of drippers. Journal of the American Society for Horticultural Science, v.69, p.481-489, 1994.

DAVIES, F.S.; ALBRIGO, L.G. Citrus. Wallingford: CAB International, 1994. $254 \mathrm{p}$

DAVIES, W.J.; ZHANG, J. Root signals and the regulation of growth and development of plants in drying soil. Annual Review of Plant Physiology and Plant Molecular Biology, v.42, p.55-76, 1991.

DOMINGO, R.; RUIZ-SANCHEZ, M.C.; SANCHEZ-BLANCO, N.J.; TORRECILLAS, A. Water relations, growth and yield of Fino lemon trees under regulated deficit irrigation. Irrigation Science, v.16, p.115123, 1996

ELFVING, D.C.; KAUFMANN, M.R.; HALL, A.E. Interpreting leaf water potential measurements with a model of soil-plant-atmosphere continuum. Physiologia Plantarum, v.27, p.161-168, 1972.

FOLEGATTI, M.V.; SILVA, T.J.A.; CASARINI, E. O manejo da irrigação como elemento essencial na utilização racional dos recursos hídricos. In: THAME, L.C.M. (Ed.) A cobrança pelo uso da água na agricultura. Embu: IQUAL Editora, 2004. p.213-219.

GINESTAR, C.; CASTEL, J.R. Responses of young Clementine citrus trees to water stress during different phenological periods. Journal of the American Society for Horticultural Science, v.71, p.551-559, 1996.

GONZÁLEZ-ALTOZANO, P.; CASTEL, J.R. Regulated deficit irrigation in 'Clementina de Nules' citrus trees. II: Vegetative growth. Journal of the American Society for Horticultural Science, v.75, p.388-392, 2000.

GOWING, D.J.; DAVIES, W.J.; JONES, H.G. A positive root sourced signa as an indicator of soil drying in apple, Malus x domestica Borkh. Journal of Experimental Botany, v.41, p.1535-1540, 1990.

HALL, A.E.; CAMACHO-B, S.E.; KAUFMANN, M.R. Regulation of water loss by citrus leaves. Physiologia Plantarum, v.33, p.62-65, 1975.

HUTCHINSON, D.J. Influence of rootstock on the performance of 'Valencia' sweet orange. In: INTERNATIONAL CITRUS CONGRESS, 2., Orlando, 1977. Proceedings. Gainesville: International Society of Citriculture, 1977. p.523-525.

JONES, H.G. Irrigation scheduling: advantages and pitfalls of plant-based methods. Journal of Experimental Botany, v.55, p.2427-2436, 2004.

LIU, F.; JENSEN, C.R.; ANDERSEN, M.N. Hydraulic and chemical signals in the control of leaf expansion and stomatal conductance in soybean exposed to drought stress. Functional Plant Biology, v.30, p.65-73, 2003.

MACHADO, E.C.; MEDINA, C.L.; GOMES, M.M.A. Teor de água no substrato de crescimento e fotossíntese em laranjeira 'Valência'. Bragantia, v.58, p.217-226, 1999.

MACHADO, E.C.; MEDINA, C.L.; GOMES, M.M.A.; HABERMANN, G. Variação sazonal da fotossíntese, condutância estomática e potencial da água na folha de laranjeira 'Valência'. Scientia Agricola, v.59, p.53$58,2002$.

MARLER, T.E.; DAVIES, F. Microsprinkler irrigation and growth of young 'Hamilin' orange trees. Journal of the American Society for Horticultural Science, v.115, p.45-51, 1990.

MEDINA, C.L. Fisiologia da produção. In: MATTOS JR., D.; DE NEGRI, J.D.; FIGUEIREDO, J.O. (Ed.). Lima ácida Tahiti. Campinas: Instituto Agronômico, 2003. p.67-80

MEDINA, C.L.; MACHADO, E.C. Trocas gasosas e relações hídricas em laranjeira 'Valência' enxertada sobre limoeiro 'Cravo' e Trifoliata e submetida à deficiência hídrica. Bragantia, v.57, p.15-22, 1998.

MEDINA, C.L.; MACHADO, E.C.; GOMES, M.M.A. Condutância estomática, transpiração e fotossíntese em laranjeira 'Valência' sob deficiência hídrica. Revista Brasileira de Fisiologia Vegetal, v.11, p.2934, 1999. 
PIRES, R.C.M. Manejo da água na irrigação dos citros. Laranja, v.1, p.237260, 1992.

RAIJ, B. van; SILVA, N.M.; BATAGLIA, O.C.; QUAGGIO, J.A.; HIROCE, R.; CANTARELlA, H.; BELLINAZZI JR., R.; DECHEN, A.R.; TRANI, P.E. Recomendações de adubação e calagem para o Estado de São Paulo. Campinas: Instituto Agronômico, 1992. 107p. (Boletim Técnico, 100).

SAVÉ, R.; BIEL, C.; DOMINGO, R.; RUIZ-SÁNCHEZ, M.C.; TORRECILLAS, A. Some physiological and morphological characteristics of citrus plants for drought resistance. Plant Science, v.110, p.167-172, 1995

SCHOLANDER, P.F.; HAMMEL, H.T.; BRADSTREET, E.D.; HEMMINGSEN, E.A. Sap pressure in vascular plants. Science, v.148, p.339-346, 1965.

SHALHEVET, J.; LEVY, Y. Citrus trees In: STEWART, B.A.; NIELSEN, D.R. (Ed.) Irrigation of agricultural crops. Madison: ASA, 1990. p.951-986. (Agronomy, 30).

SMAJSTRLA, A.G.; KOO, R.C.J. Effects of trickle irrigation methods and amounts of water applied on citrus yields. Proceedings of the Florida State Horticultural Society, v.97, p.3-7, 1984.

SOUTHWICK, S.M.; DAVENPORT, T.L. Modification of water stressinduced floral response in 'Tahiti' lime. Journal of the American Society for Horticultural Science, v.112, p.231-236, 1987.

SOUZA, M.J.H.; RAMOS, M.M.; SIQUEIRA, D.L.; COSTA, L.C.; LHAMAS, A.J.M.; MANTOVANI, E.C.; CECON, P.R.; SALOMÃO, L.C.C. Produção e qualidade dos frutos de limeira ácida 'Tahiti' submetida a diferentes porcentagens de área molhada. Revista Brasileira de Engenharia Agrícola e Ambiental, v.7, p.245-250, 2003.

SYVERTSEN, J.P. Minimum leaf water potential and stomatal closure in citrus leaves of different ages. Annals of Botany, v.49, p.827-834, 1982.
SYVERTSEN, J.P.; SMITH JR., M.L.; ALLEN, J.C. Growth rate and water relations of citrus leaf flushes. Annals of Botany, v.47, p.97-105, 1981.

SYVERTSEN, J.P.; LLOYD, J.J. Citrus. In: SCHAFFER, B.; ANDERSEN (Ed.) Handbook of environmental physiology of fruits crops: Subtropical and tropical crops. Boca Raton: CRC Press, 1994. v.2, p.6599.

TOMMASELLI, J.T.G.; BACCHI, O.O.S. Calibração de um equipamento de TDR para medida de umidade dos solos. Pesquisa Agropecuária Brasileira, v.36, p.1145-1154, 2001.

URRIBARRÍ, L.L.; ARAUJO. F.B.; VILLALOBOS, R. Una metodologia para la estimación del estrés hídrico en plantas de lima 'Tahití' (Citrus x 'Tahití'). Revista de la Facultad de Agronomia, v.13, p.49-60, 1996.

VAN GENUCHTEN, M.Th. A closed form equation for predicting the hydraulic conductivity of unsaturated soils. Soil Science Society of America Journal, v.44, p.892-898, 1980.

VERMEIREN, L.; JOBLING, G.A. Irrigação localizada. Campina Grande: UFPB, 1997. 184p. (Estudos FAO: Irrigação e Drenagem, 36).

VESELOVA, S.; FARHUTDINOV, R.; MITRICHENKO, A.; SYMONYAN, M.; HARTUNG, W. The effect of root cooling on hormone content, leaf conductance and root hydraulic conductivity of durum wheat seedlings (Triticum durum L.). Bulgarian Journal of Plant Physiology, p.360366, 2003. Special issue.

VU, J.C.V.; YELENOSKY, G. Water deficit and associated changes in some photosynthetic parameters in leaves of 'Valencia' orange (Citrus sinensis [L.] Osbeck). Plant Physiology, v.88, p.375-378, 1988.

WONG, S.C.; COWAN, I.R.; FARQUHAR, G.D. Stomatal conductance correlates with photosynthetic capacity. Nature, v.282, p.424-426, 1979.

Received April 29, 2005

Accepted September 02, 2005 